\title{
Nickel(II) Selective PVC-Based Membrane Sensor Using a Schiff Base
}

\author{
B. Rezaei, H. Hadadzadeh, and A. Azimi \\ Department of Chemistry, Isfahan University of Technology, Isfahan 84156-83111, Iran \\ Correspondence should be addressed to B. Rezaei, rezaei@cc.iut.ac.ir
}

Received 2 November 2010; Revised 6 February 2011; Accepted 10 March 2011

Academic Editor: David Ramaker

Copyright () 2011 B. Rezaei et al. This is an open access article distributed under the Creative Commons Attribution License, which permits unrestricted use, distribution, and reproduction in any medium, provided the original work is properly cited.

A polyvinylchloride (PVC) membrane optode was prepared by using 1,2-di(o-salicylaldiminophenylthio)ethane ( $\left.\mathrm{H}_{2} \mathrm{DSALPTE}\right)$ as a chelating reagent for selective determination of $\mathrm{Ni}$ (II) ions. The optimized membranes incorporating $\mathrm{H}_{2}$ DSALPTE as an ionophore, sodium tetraphenylborate (NaTPB) as an anion excluder, and tributyl phosphate (TBP) as a solvent mediator were prepared and applied for determination of $\mathrm{Ni}(\mathrm{II})$ ions. The membrane responded to $\mathrm{Ni}$ (II) ion by changing the color from yellow to green in an acetate buffer solution at $\mathrm{pH}$ 6.0. The best performance was observed when the membrane having a composition of $3.17 \%$ ligand, $31.64 \%$ PVC, $63.29 \%$ TBP, and 1.90\% NaTPB. The membrane can be worked well over a wide concentration range from $1.0 \times 10^{-5}$ to $5.0 \times 10^{-3} \mathrm{M}$. The membrane exhibited a detection limit of $8.51 \times 10^{-6} \mathrm{M}$, and the response time of the membrane was within 7-12 min depending on the concentration of $\mathrm{Ni}$ (II) ions. The selectivity of the probe towards nickel determination was found to be very good. Experimental results showed that the probe could be used as an effective tool in analyzing the $\mathrm{Ni}$ (II) content of water samples.

\section{Introduction}

Over the years, nickel has been regarded as a potentially toxic metal. The main source of nickel in aquatic systems is decomposition or degradation of rocks and soil, biological cycles and especially industrial processes, and water disposal [1]. The maximum recommended concentration of $\mathrm{Ni}$ (II) ions in drinking water for livestock is $2.5 \mathrm{mg} / \mathrm{mL}$ [2]. Nickel is well known as a toxic metal that can cause cancer of nasal lungs, dermatitis, asthma, and disorders of central nervous system [3]. Thus, due to the urgent need for selective monitoring of $\mathrm{Ni}(\mathrm{II})$ in many industrial, environmental, and food samples, there have been a number of recent reports in the literature [4-8]. A number of methods, such as atomic absorption spectrometry (AAS), flame atomic absorption spectrometryelectrothermal atomization (AAS-ETA) [9-12], inductively coupled plasma-atomic emission spectroscopy (ICP-AES), and flame photometry [13], can be used for determination of nickel. However, these methods generally require sample pretreatment and infrastructure backup and are, therefore, not very convenient for routine analysis of large number of environmental samples. Thus, there is critical need for the development of selective, portable, inexpensive diagnostic tool for the determination of nickel. Optical chemical sensors or optodes have become an important research area since their introduction two decades ago. Optical sensors are compact and ideally suited to miniaturization, while at the same time they are resisting to electrical interference and utilize the simplicity of photometric measurements. Many optical chemical sensors utilize colored complexes [14-16] or redox reagents $[17,18]$ immobilized in suitable matrix. Several methods have been used to immobilize reagents in optical sensors used for heavy metal ions, such as covalent binding $[19,20]$, electrostatic attraction to a resin $[21,22]$, incorporation into PVC membranes [23-28], and entrapment inside Nafion films [14, 17, 29]. Since polymer matrix, particularly PVC, can easily trap the ionophorebased liquid membrane system, a great deal of interesting has been focused on the PVC-based membranes [30-34].

In this paper, results on the PVC matrix membranes sensor incorporating 1,2-di( $o$-salicylaldiminophenylthio)ethane $\left(\mathrm{H}_{2}\right.$ DSALPTE) ionophore (Scheme 1$)$ for the determination of $\mathrm{Ni}(\mathrm{II})$ in aqueous solutions have been presented and discussed. 


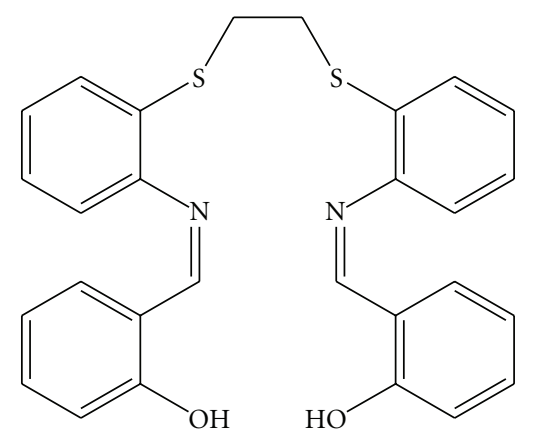

Scheme 1: Structure of $\mathrm{Sal}_{2}$ dapte.

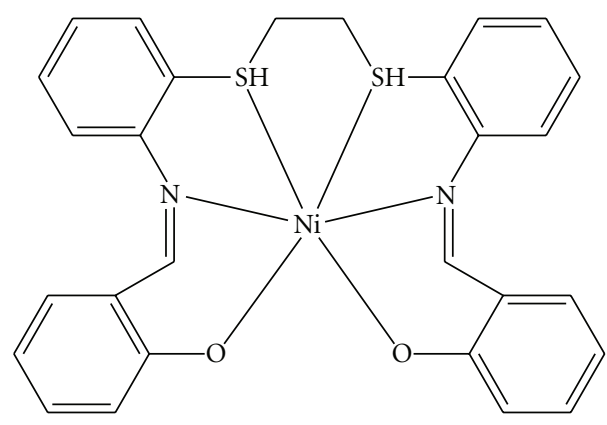

Scheme 2: Structure of complex Ni(Sal ${ }_{2}$ dapte).

\section{Experimental}

2.1. Reagents and Solutions. All of the chemicals used were of analytical reagent grade (Merck). 1,2-Di(o-salicylaldiminophenylthio)ethane $\left(\mathrm{H}_{2}\right.$ DSALPTE) was synthesized according to the literature [35]. The $\mathrm{Ni}(\mathrm{II})$ stock solution $(0.10 \mathrm{M})$ was prepared by dissolving of $1.4540 \mathrm{~g} \mathrm{Ni}\left(\mathrm{NO}_{3}\right)_{2} \cdot 6 \mathrm{H}_{2} \mathrm{O}$ in water and diluted to $50 \mathrm{~mL}$ in a standard flask. Sample solutions were prepared by appropriate dilution. Other reagents such as ortho-nitrophenyl octyl ether (o-NPOE), sodium dibutyl phthalate (Na-DBP), dioctyl sebacate (DOS), sodium tributyl phosphate (Na-TBP), high molecular weight PVC (HMW-PVC), and tetrahydrofuran (THF), all from Fluka or Merck chemical companies, were used as received. Other chemicals were of reagent grade and were used without further purification. Direct-Q water was used throughout the experiments.

2.2. Apparatus. UV-vis spectra were obtained with a UV/VIS/NIR JASCO spectrophotometer (model V-570) connected to a Pentium IV computer used for getting the absorption spectra and absorbance measurements. A Metrohm pH meter (model 780) with a combined double junction glass electrode, calibrated against two standard buffer solutions at $\mathrm{pH} 4.0$ and 7.0, was used for monitoring $\mathrm{pH}$ values. All measurements were made in the absorbance mode. The $\mathrm{pH}$ of the solutions was kept constant by using $0.1 \mathrm{M}$ acetate buffer at $\mathrm{pH}$ 6.0.

2.3. Preparation of Optical Sensor. The membrane solutions were prepared by mixing appropriate amounts of active components; $50 \mathrm{mg}$ PVC, $100 \mathrm{mg}$ TBP as plasticizer, $5.0 \mathrm{mg}$ of $\mathrm{H}_{2}$ DSALPTE, and $3.0 \mathrm{mg}$ anionic additive in a glass vial and dissolving the components in $1.5 \mathrm{~mL}$ of THF. The solution was immediately shaken vigorously to achieve complete homogeneity. The glass plates by approximately dimensions of $0.9 \mathrm{~cm} \times 3 \mathrm{~cm}$ were cleaned with pure THF to remove organic impurities and dust. Then, $25 \mu \mathrm{L}$ of the above cocktail was injected with $100 \mu \mathrm{L}$ glass syringe to the glass plate and spread evenly by using a capillary glass tube. Finally, the membrane was located in ambient air and allowed to dry for few minutes.

2.4. Absorbance Measurements. The prepared membranes were put in an acetate buffer solution of $\mathrm{pH} 6.0$ for $10 \mathrm{~min}$ to reach equilibrium, and after a conditioning time, its spectrum was recorded. A membrane without ionophore was used as reference for absorbance measurement. Then, the sensor was immersed into a $\mathrm{Ni}$ (II) solution in acetate buffer ( $\mathrm{pH}$ 6.0) for $7 \mathrm{~min}$. Finally, the sensor was washed with distilled water and dried in air. The absorbance of the membrane was measured over the wavelength range of 320$500 \mathrm{~nm}$.

\section{Results and Discussion}

3.1. Spectral Characteristic. The key ingredient of such plasticized PVC membranes is the incorporated carrier that defines the selectivity of the sensor via selective complex formation with the certain cation. Due to sufficient insolubility of $\mathrm{H}_{2}$ DSALPTE in water and the presence of six donor atoms $\left(\mathrm{N}_{2} \mathrm{~S}_{2} \mathrm{O}_{2}\right)$ in its structure, it was expected to act as a suitable ion carrier in the PVC membranes for complex formation with $\mathrm{Ni}$ (II) ions (Scheme 2). The chelate, $\mathrm{H}_{2}$ DSALPTE, has two acidic phenolic protons and acts as dianionic hexadentate ligand. As can be seen in Scheme 2, coordination of DSALPTE ${ }^{2-}$ to Ni(II) leads to the formation of five chelate rings (three five-membered rings and two six-membered rings). Thus, it is able to be a photometric reagent for $\mathrm{Ni}(\mathrm{II})$ ions at a suitable $\mathrm{pH}$. Figure 1 shows the absorption spectra of the membrane which were obtained after being equilibrated in acetate buffer solution $(\mathrm{pH}$ 6.0) containing different concentrations of $\mathrm{Ni}(\mathrm{II})$ ion. The spectral change (decrease in absorption band at $350 \mathrm{~nm}$ and increase in the absorption band at $443 \mathrm{~nm}$ ) is a result of an increase in $\mathrm{Ni}$ (II) ion concentration in the membrane which is due to the extraction of $\mathrm{Ni}$ (II) ion into the membrane. The formation of the complex causes a change in color of the reagent phase from yellow to green.

3.2. Measuring Principle. Measuring principle can be explained as follows. The membrane response may be defined as the ratio of the concentration of the free ligand $[C]$ to the total amount present in the membrane $\left[C_{T}\right]$, that is, $\alpha=[C] /\left[C_{T}\right]$. Then, the $\alpha$ value can be calculated by absorbance measurements at $\lambda_{\max }$ of complexed ligand as $\alpha=\left(A_{C}-A\right) /\left(A_{C}-A_{L}\right)$, where $A_{C}$ is the absorbance value of the membrane for complete complexation (i.e., at $\alpha=0$ ), $A_{L}$ is the absorbance value of the membrane for the free 


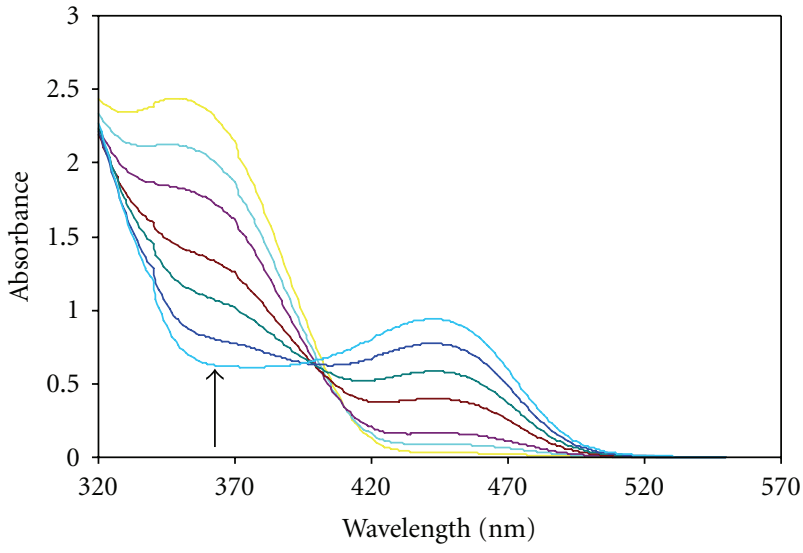

FIGURE 1: Absorption spectra for the immobilized $\mathrm{Sal}_{2}$ dapte in the presence of $0-5 \times 10^{-2} \mathrm{M}$ of $\mathrm{Ni}^{2+}$. Arrow indicates increase in Nickel concentration.

ligand (i.e. at $\alpha=1$ ) [36], and $A$ is absorbance measured at any time during the titration procedure.

\subsection{Effect of pH and Buffer Type on Response of the Optode.} The equilibrium of the complexation reaction of $\mathrm{H}_{2}$ DSALPTE with $\mathrm{Ni}(\mathrm{II})$ ion is affected by the solution $\mathrm{pH}$. Figure 2 shows the effect of $\mathrm{pH}$ values on the absorbance intensity of the optode membrane. The absorbance measurements were made for $30 \mu \mathrm{M} \mathrm{Ni(II)}$ ion with different $\mathrm{pH}$ values at $526 \mathrm{~nm}$. The blank membrane (membrane without $\mathrm{H}_{2}$ DSALPTE in buffer solution) was taken as the reference. All the absorbances were measured with respect to the conditioning solution, that is, as $\Delta A=A-A_{0}$, where $A$ and $A_{0}$ are the absorbance of the sensor in $\mathrm{Ni}(\mathrm{II})$ and buffer solutions, respectively, at $443 \mathrm{~nm}$. The $\mathrm{pH}$ values were adjusted by the addition of dilute $\mathrm{NaOH}$ or $\mathrm{HCl}$. As can be seen in Figure 2, as the $\mathrm{pH}$ increases from 1 to 9 , the difference in absorbance reaches a maximum at $\mathrm{pH}$ 6.0, and then decreases. Because at low $\mathrm{pH}$ values $(\mathrm{pH}<6.0)$, complexation is weak. The $\mathrm{pH}$ values $>8.5$ were not examined because hydrolysis of $\mathrm{Ni}$ (II) complex may occur. Thus, the response was optimum at $\mathrm{pH}$ 6.0. Response studies of this membrane to various buffer solutions including acetate, phosphate, universal, and phthalate $(\mathrm{pH} 6.0$ and $0.1 \mathrm{M}$ ) showed that it responded best to acetate buffer. In acetate buffer, the membrane optode showed better sensitivity and response time. Therefore, acetate buffer was selected as the optimum buffer for further studies.

\subsection{Effect of Membrane Composition}

3.4.1. Choice of Solvent Mediator (Plasticizer). The use of 61$65 \%$ plasticizer in the preparation of the PVC membranes resulted in optimum physical properties, as well as relatively high mobility of their constituents [37-40]. To select the best plasticizer, we conducted a preliminary study with different plasticizers (TBP, $o$-NPOE, DOS, DBP). The absorbance measurements were made for $50 \mu \mathrm{M} \mathrm{Ni(II)} \mathrm{ion.} \mathrm{The} \mathrm{blank}$ membrane (membrane in buffer solution without $\mathrm{Ni}(\mathrm{II})$ ion)

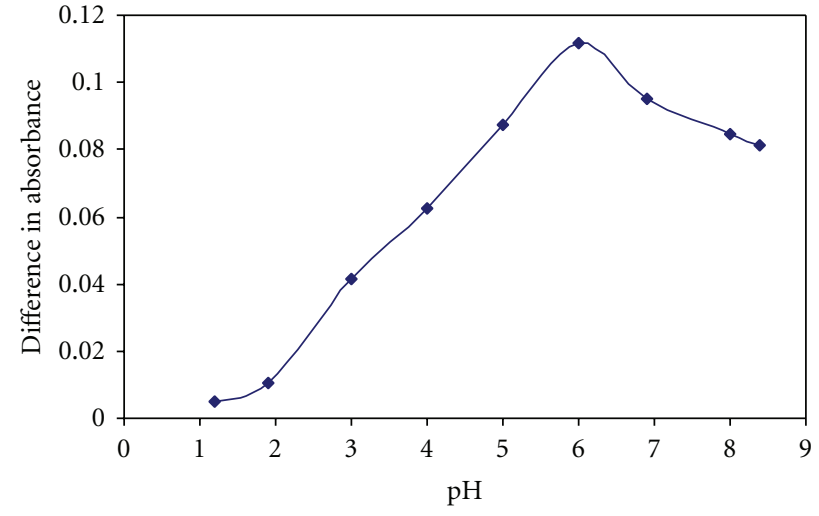

FIGURE 2: Efect of $\mathrm{pH}$ on the response of membrane in the presence of $5 \times 10^{-5} \mathrm{M}$ thorium at $443 \mathrm{~nm}$.

was taken as the reference. The results are shown in Table 1. As can be seen for the case of TBP, the membrane response towards $\mathrm{Ni}$ (II) ions gives the widest working dynamic range and DOS does not give any response. The membranes containing TBP revealed the best physical properties. This is most probably due to the presence of phosphate group, which facilitates the extraction and complexation of the $\mathrm{Ni}(\mathrm{II})$ ions into the bulk of PVC-membranes. TBP was thus used as the plasticizer for all subsequent experiments.

\subsubsection{Effect of the Amount of $H_{2} D S A L P T E$ on the Optode} Response. Different compositions (w/w) of the constituents of membrane were tried for the improvements of the response characteristics. To this purpose, seven membranes by different amount of $\mathrm{H}_{2}$ DSALPTE were prepared to optimize the amount of ionophore. The total amounts of PVC, TBP, and NaTPB (anionic additive) were constant, and also the ratio TBP/PVC was 2.0 in each membrane. The effect of the amount of $\mathrm{H}_{2}$ DSALPTE on the response of the membrane is illustrated in Figure 3. The absorbance measurements at $443 \mathrm{~nm}$ were made for $50 \mu \mathrm{M} \mathrm{Ni(II).} \mathrm{The}$ blank membrane (membrane without $\mathrm{H}_{2}$ DSALPTE in the buffer solution) was taken as the reference. As can be seen from Figure 3, increase in the amount of $\mathrm{H}_{2}$ DSALPTE results in an increase in difference in absorbance. It is important to mention that no considerable improvement was observed in any of these characteristics when the amount of $\mathrm{H}_{2}$ DSALPTE was increased from $5.0 \mathrm{mg}$ to $7.0 \mathrm{mg}$. Therefore, the membrane with $5.0 \mathrm{mg}$ of ionophre with $3.17 \% \mathrm{w} / \mathrm{w}$ was chosen as the optimum.

3.4.3. Effect of the Amount of Anionic Additive (NaTPB) on the Optode Response. Although neutral membranes may work properly even when they contain only a very small amount of ionic sites (e.g., as impurities), the addition of a salt of lipophilic ion is advisable and beneficial for various other reasons as well. In fact, it has been demonstrated that the negatively charged lipophilic additives can be improved the adsorption of $\mathrm{Ni}(\mathrm{II})$ ions by the membrane and prevented 
TABLE 1: Effect of amount of the type of Plasticizer on dynamic range of membrane, $\mathrm{pH}=6.0$ at $443 \mathrm{~nm}$.

\begin{tabular}{|c|c|c|c|c|c|}
\hline \multirow{2}{*}{ Number membrane } & \multicolumn{4}{|c|}{ Composition of membrane } & \multirow{2}{*}{ Dynamic range $(\mathrm{M})$} \\
\hline & PVC (mg) & Plasticizer $(100 \mathrm{mg})$ & Ionophore ( $\mathrm{Sal}_{2}$ dapte $)$ & Anionic additive (NaTPB) & \\
\hline 1 & 50 & DOS & $5.0 \mathrm{mg}$ & $3.0 \mathrm{mg}$ & - \\
\hline 2 & 50 & DBP & $5.0 \mathrm{mg}$ & $3.0 \mathrm{mg}$ & $1.0 \times 10^{-2}-1.0 \times 10^{-4}$ \\
\hline 3 & 50 & TBP & $5.0 \mathrm{mg}$ & $3.0 \mathrm{mg}$ & $5.0 \times 10^{-3}-1.0 \times 10^{-5}$ \\
\hline 4 & 50 & o-NPOE & $5.0 \mathrm{mg}$ & $3.0 \mathrm{mg}$ & $5.0 \times 10^{-3}-5.0 \times 10^{-5}$ \\
\hline
\end{tabular}

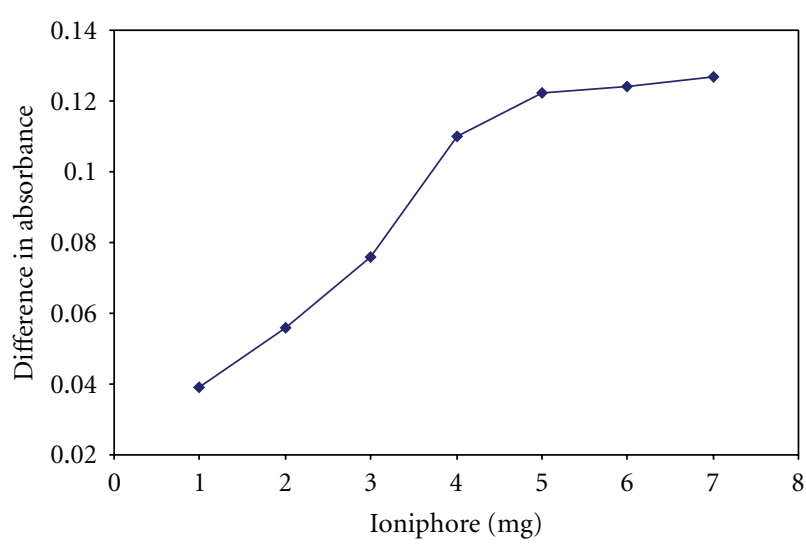

Figure 3: Effect of amount of Ionophore ( $\mathrm{Sal}_{2}$ dapte) on the response of membrane in $5.0 \times 10^{-5} \mathrm{M} \mathrm{Ni}(\mathrm{II}), \mathrm{pH}=6.0$ at $443 \mathrm{~nm}$.

from interference by the anions. Therefore, the selectivity increases significantly for determination of $\mathrm{Ni}(\mathrm{II})$. To optimize the amount of NaTPB, six membranes by different amount of NaTPB from $0 \mathrm{mg}$ to $5.0 \mathrm{mg}$ were prepared. The total amounts of PVC, TBP, and $\mathrm{H}_{2}$ DSALPTE were constant. As shown in Figure 4, increase in the amount of NaTPB more than $3.0 \mathrm{mg}$ results in an increase of interference of foreign ions. Also, the membrane with $1.90 \% \mathrm{w} / \mathrm{w}$ of NaTPB has the best sensitivity (3.0 mg of NaTPB to stead $50 \mathrm{mg}$ of PVC) and was selected for further Studies.

Based on the results of the above-mentioned studies, the membrane obtained from a mixture of PVC $(50 \mathrm{mg}$, $31.64 \%$ ), TBP (100 mg, 63.29\%), $\mathrm{H}_{2}$ DSALPTE (5.0 mg, $3.17 \%)$, and NaTPB $(3.0 \mathrm{mg}, 1.90 \%)$ in THF (1.5 mL) gave the best results and was used as the membrane with optimized composition.

3.5. Response Time. An important analytical feature of any optode is its response time. The response time of the present optode is controlled by the time required for the analyte to diffuse from the bulk of the solution toward the membrane interface to associate with ligand. The response of the membrane was found to reach $95 \%$ of the total signal in $7-$ 12 min depending on the concentration of $\mathrm{Ni}(\mathrm{II})$. In general, the response time is more rapid when proceeding from dilute to concentrated solution.

3.6. Dynamic Range and Detection Limit. The optical response of the proposed $\mathrm{Ni}$ (II)-selective absorbance sensor at different $\mathrm{Ni}$ (II) ion concentrations, under optimal experimental

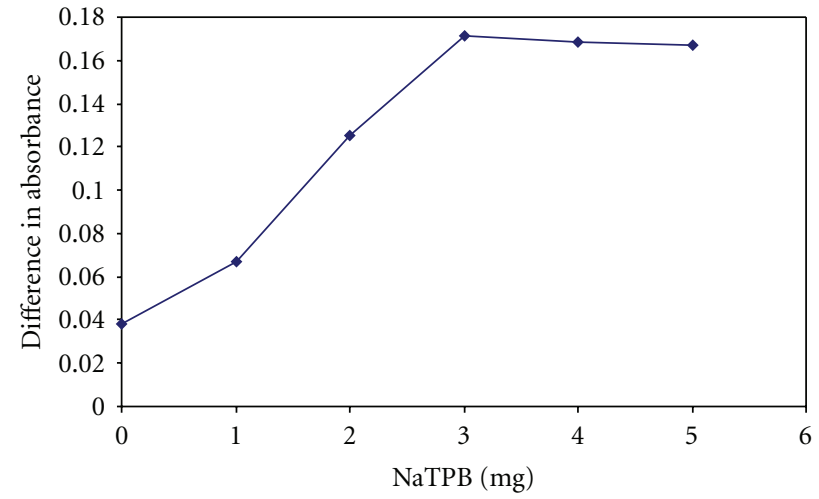

Figure 4: Effect of amount of NaTPB on the response of membrane in $5.0 \times 10^{-5} \mathrm{M} \mathrm{Ni}(\mathrm{II}), \mathrm{pH}=6.0$ at $443 \mathrm{~nm}$.

conditions, is shown in Figure 1. The dynamic range response, which is an important characteristic for any ionselective membrane sensor, was studied by plotting 1- $\alpha$ versus logarithm of $\mathrm{Ni}$ (II) ion concentration (M) (Figure 5). A concentration of $5.0 \times 10^{-2} \mathrm{M}$ was found as the concentration of $\mathrm{Ni}$ (II) ion that saturates the membrane optode. This curve can be suitably used as a calibration curve for the determination of $\mathrm{Ni}$ (II) ions in a concentration range from $1.0 \times 10^{-5}$ to $5.0 \times 10^{-3} \mathrm{M}$ with equation of $y=$ $0.2917 \log \left[\mathrm{Ni}^{2+}\right]+1.4799\left(R^{2}=0.9924\right)$. The limit of detection (LOD) based on $3 \sigma$ of the blank was $8.51 \times 10^{-6} \mathrm{M}$ $(n=7)$.

3.7. Regeneration of Optode Membrane. Some reagents including $\mathrm{HCl}, \mathrm{HNO}_{3}, \mathrm{H}_{3} \mathrm{PO}_{4}, \mathrm{H}_{2} \mathrm{SO}_{4}, \mathrm{NaSCN}, \mathrm{EDTA}, \mathrm{NaF}$, and 5-sulfosalicylic acid dihydrate were studied as regenerating reagents. It was found that none of the above reagents or their mixtures could regenerate optode membrane completely and, thus, the membrane could be used as a probe for $\mathrm{Ni}(\mathrm{II})$ determination.

3.8. Reproducibility, Short-Term Stability, and Lifetime. The membrane reproducibility was obtained by preparing eight membranes using the same membrane solution and membrane preparations as described in Section 2.3. The R.S.D. value for these membranes was $6.5 \%$, indicating that the procedure used for preparation of the membranes had an acceptable reproducibility.

The short-term stability of the optode membrane was investigated by its absorbance intensity measurements in 


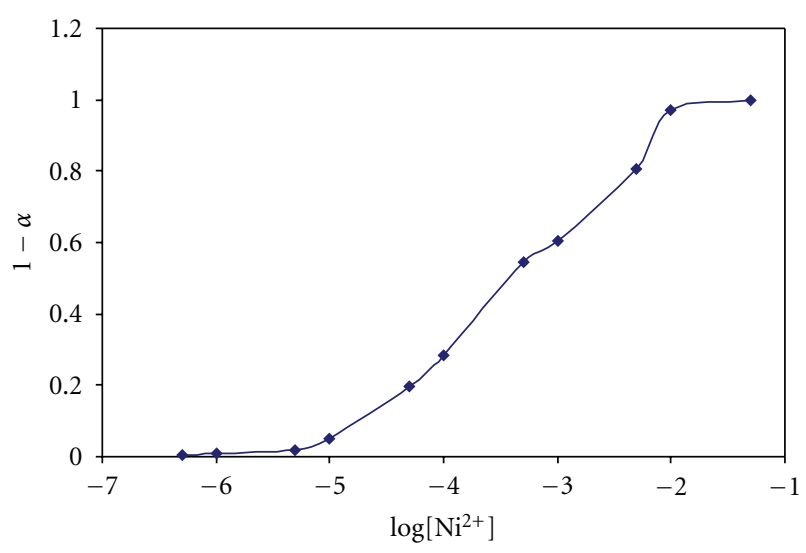

FIgURE 5: Calibration curve at $443 \mathrm{~nm}$.

contact with a $5.0 \times 10^{-5} \mathrm{M}$ solution of $\mathrm{Ni}(\mathrm{II})$ buffered at $\mathrm{pH} 6.0$ over a period of $5 \mathrm{~h}$. During this period, there was no evidence of leakage of $\mathrm{H}_{2}$ DSALPTE from the membrane.

The lifetime of the sensor was investigated, where the membranes were stored in laboratory ambient condition. The responses were measured daily, and the results were compared with those of the first day. Variation of the response was considered significant if it was different from the average \pm 3 S.D. of the response measured in the first day. A significant change in its response was noticed after 9 days of continuous use.

3.9. Selectivity. The selectivity behavior is obviously one of the most important characteristics of an ion-selective optode, which reflects the relative response of the optode for primary ion over diverse ions present in solution determining whether a reliable measurement in the target sample is possible. Thus, the influence of a number of common metal ions on the response of the proposed $\mathrm{Ni}(\mathrm{II})$-optical sensor was investigated. To determine the selectivity of the optode membrane, the membrane was tested for the determination of $5.0 \times 10^{-5} \mathrm{M}$ of $\mathrm{Ni}(\mathrm{II})$ ions in the presence of different metal ions. Table 2 summarizes the tolerance ratio for several cationic and anionic species. The tolerance limit was taken as the concentration of the interfering species causing an error of not more than \pm 3 S.D. in the determination of nickel, where S.D. is the standard deviation obtained in the replicate measurements of $5.0 \times 10^{-5} \mathrm{M} \mathrm{Ni}(\mathrm{II})$. The results of Table 2 indicate that several anionic and cationic species can be tolerated at much higher concentrations than $\mathrm{Ni}(\mathrm{II})$.

3.10. Analytical Application. To test the practical application of the present sensor, some drinking, river (Zayandehrod), and waste water samples, that is spiked with different amounts of $\mathrm{Ni}$ (II) ion, were measured by the proposed optode membrane. The $\mathrm{pH}$ of prepared water samples were adjusted by the addition of $5 \mathrm{~mL}$ of acetate buffer ( $\mathrm{pH} 6.0$ ) to $20 \mathrm{~mL}$ of them. Table 3 shows that by the use of the proposed optode very satisfactory recoveries are obtained for $\mathrm{Ni}$ (II) determination in real water samples.
TABLE 2: Effect of foreign ion on the determination of $5.0 \times 10^{-5} \mathrm{M}$ Nickel ion.

\begin{tabular}{lc}
\hline Species & $\begin{array}{c}\text { Tolerance limit } \\
\left(\mathrm{M}_{\mathrm{ion}} / \mathrm{M}_{\mathrm{Ni}(\mathrm{II})}\right)\end{array}$ \\
\hline $\mathrm{Na}^{+}, \mathrm{K}^{+}, \mathrm{Ba}^{2+}, \mathrm{Cl}^{-}, \mathrm{BrO}_{3}{ }^{-}, \mathrm{NO}_{3}{ }^{-}, \mathrm{SO}_{4}{ }^{2-}$ & 500 \\
$\mathrm{Zn}^{2+}, \mathrm{Hf}^{+}, \mathrm{Tl}^{+}, \mathrm{La}^{3+}, \mathrm{Zr}^{4+}, \mathrm{Cd}^{2+}, \mathrm{F}^{-}$ & 100 \\
$\mathrm{Mn}^{2+}, \mathrm{Mg}^{2+}, \mathrm{In}^{3+}, \mathrm{Pd}^{2+}, \mathrm{Fe}^{3+}, \mathrm{Ga}^{3+}, \mathrm{Rh}^{3+}$ & 50 \\
$\mathrm{Al}^{3+}, \mathrm{Ag}^{+}, \mathrm{Co}^{2+}, \mathrm{Fe}^{2+}, \mathrm{Cr}^{2+}$ & 10 \\
$\mathrm{Hg}^{2+}, \mathrm{Cu}^{2+}$ & 5 \\
\hline
\end{tabular}

TABLE 3: Results of Nickel (II) ion determination in spiked water samples.

\begin{tabular}{lccc}
\hline Sample & Added & Found $(x \pm 3 \mathrm{~s})$ & Recovery \\
\hline Drinking water & - & $<\mathrm{DL}^{*}$ & - \\
Drinking water & $1.00 \times 10^{-5}$ & $(1.06 \pm 0.09) \times 10^{-5}$ & $\% 106.0$ \\
Drinking water & $1.00 \times 10^{-4}$ & $(9.80 \pm 0.15) \times 10^{-5}$ & $\% 98.0$ \\
River water & - & $<\mathrm{DL}^{*}$ & - \\
River water & $1.00 \times 10^{-5}$ & $(1.10 \pm 0.11) \times 10^{-5}$ & $\% 110.0$ \\
River water & $1.00 \times 10^{-4}$ & $(1.09 \pm 0.10) \times 10^{-4}$ & $\% 109.0$ \\
Waste water & - & $<\mathrm{DL}$ & - \\
Waste water & $1.00 \times 10^{-5}$ & $(1.08 \pm 0.19) \times 10^{-5}$ & $\% 108.0$ \\
Waste water & $1.00 \times 10^{-4}$ & $(1.03 \pm 0.18) \times 10^{-4}$ & $\% 103.0$ \\
\hline
\end{tabular}

${ }^{*}$ DL; detection limit.

TABLe 4: Response characteristics of the proposed method are compared with reported methods.

\begin{tabular}{|c|c|c|c|}
\hline $\begin{array}{l}\text { Linear dynamic } \\
\text { Range (M) }\end{array}$ & $\begin{array}{l}\text { Detection } \\
\text { limit }(M)\end{array}$ & $\begin{array}{l}\text { Response } \\
\text { time (min) }\end{array}$ & Interferences \\
\hline $\begin{array}{l}5.0 \times 10^{-6}-1.0 \times \\
10^{-3}[41]\end{array}$ & $\begin{array}{c}5.2 \times \\
10^{-7}\end{array}$ & 10 & $\begin{array}{c}\mathrm{Pb}^{2+}, \mathrm{Fe}^{3+}, \mathrm{Al}^{3+}, \mathrm{Fe}^{2+} \\
\mathrm{Cu}^{2+}\end{array}$ \\
\hline $\begin{array}{l}8.52 \times 10^{-6}-3.4 \times \\
10^{-4}[42]\end{array}$ & $\begin{array}{c}5.11 \times \\
10^{-6}\end{array}$ & 3 & $\begin{array}{l}\mathrm{Cd}^{2+}, \mathrm{Cu}^{2+}, \mathrm{Co}^{2+} \\
\quad \mathrm{Zn}^{2+}, \mathrm{Hg}^{2+}\end{array}$ \\
\hline $\begin{array}{l}1.0 \times 10^{-5} \text { to } 5.0 \times \\
10^{-3} \text {, this work }\end{array}$ & $\begin{array}{c}8.51 \times \\
10^{-6} \\
\end{array}$ & 7 & $\mathrm{Hg}^{2+}, \mathrm{Cu}^{2+}$ \\
\hline
\end{tabular}

3.11. Response Characteristics. The proposed sensor is a bulk optode, the increasing of ligand on film redound to the increasing of the sensitivity and used entrapment method for immobilization of indicator that elimination the agglomeration of indicator on the membrane and its leaching into the solutions. Agglomeration and leaching of indicator are a severe problem in physical adsorption immobilization. Covalent bonding that is covalent linkage of the dye to a suitable matrix appears to be efficient immobilization method since the resulting membranes do not leach, but most of time decrease activity of adsorption site.

In the Table 4, response characteristics of the proposed method are compared with two reported methods. In comparison with two methods $[41,42]$, our proposed method is more selective. 


\section{Conclusion}

An optical sensor was designed for determination of $\mathrm{Ni}$ (II) ions. For this propose, plasticized PVC membrane with good optical and mechanical properties were used as a substrate for immobilization of reagents. The sensor responded to $\mathrm{Ni}$ (II) ion by changing the color from yellow to green. It was applied to determine the concentration of $\mathrm{Ni}$ (II) ions in real samples.

\section{Acknowledgment}

Support by Isfahan University of Technology (IUT) is gratefully acknowledged.

\section{References}

[1] E. Merian, Ed., Metals and Their Compounds in the Environment, vol. 22, part 2, VCH, New York, NY, USA, 1991.

[2] H. L. Bohn, B. L. McNeal, and G. A. O'Connor, Soil Chemistry, Wiley Interscience, Chichester, UK, 2nd edition, 1985.

[3] S. Hernburg, J. Kikkane, G. Mellin, and H. Lilivs, Archives of EnvironmentalHealth, vol. 21, p. 140, 1970.

[4] G. N. Rao, S. Srivastava, S. K. Srivastava, and M. Singh, "Chelating ion-exchange resin membrane sensor for nickel(II) ions," Talanta, vol. 43, no. 10, pp. 1821-1825, 1996.

[5] V. K. Gupta, A. K. Jain, L. P. Singh, and U. Khurana, "Porphyrins as carrier in PVC based membrane potentiometric sensors for nickel(II)," Analytica Chimica Acta, vol. 355, no. 1, pp. 33-41, 1997.

[6] A. K. Jain, V. K. Gupta, R. D. Singh, U. Khurana, and L. P. Singh, "Nickel(II)-selective sensors based on heterogeneous membranes of macrocyclic compounds," Sensors and Actuators B, vol. 40, no. 1, pp. 15-20, 1997.

[7] V. K. Gupta, R. Prasad, P. Kumar, and R. Mangla, "New nickel(II) selective potentiometric sensor based on 5,7,12,14tetramethyldibenzotetraazaannulene in a poly(vinyl chloride) matrix," Analytica Chimica Acta, vol. 420, no. 1, pp. 19-27, 2000.

[8] M. Mazloum, M. S. Niassary, and M. K. Amini, "Pentacyclooctaaza as a neutral carrier in coated-wire ion-selective electrode for nickel(II)," Sensors and Actuators B, vol. 82, no. 2-3, pp. 259-264, 2002.

[9] J. Fries and H. Getrost, Organic Reagents for Trace Analysis, E. Merc Darmstadt, 1977.

[10] O. Haasw, M. Klarre, J. A. C. Broaekaert, and K. KrengelRothensee, "Evaluation of the determination of mercury at the trace and ultra-trace levels in the presence of high concentrations of $\mathrm{NaCl}$ by flow injection-cold vapour atomic absorption spectrometry using $\mathrm{SnCl}_{2}$ and $\mathrm{NaBH}_{4}$ as reductands," Analyst, vol. 123, p. 1219, 1998.

[11] C. E. C. Magalhães, F. J. Krug, A. H. Fostier, and H. Berndt, "Direct determination of mercury in sediments by atomic absorption spectrometry," Journal of Analytical Atomic Spectrometry, vol. 12, no. 10, pp. 1231-1234, 1997.

[12] L. W. Potts, Quantitative Analysis. Theory and Practice, Harper and Row, New York, NY, USA, 1987.

[13] P. C. Rudner, A. G. De Torres, J. M. C. Pavón, and E. R. Castellon, "Automated on-line separation-preconcentration system for inductively coupled plasma atomic emission spectrometry and its application to mercury determination," Journal of Analytical Atomic Spectrometry, vol. 13, no. 4, pp. 243-248, 1998.
[14] J. E. Madden, T. J. Cardwell, R. W. Cattrall, and L. W. Deady, "Nafion-based optode for the detection of metal ions in flow analysis," Analytica Chimica Acta, vol. 319, no. 1-2, pp. 129134, 1996.

[15] L. C. Cov, T. J. Canrdwell, R. W. Cattral, and S. D. Kolev, in Proceeding of the 12th Conference of Eurosensors, N. M. White, Ed., Southampton, UK, 1998.

[16] I. Oehme, S. Prattes, O. S. Wolfbeis, and G. J. Mohr, "The effect of polymeric supports and methods of immobilization on the performance of an optical copper(II)-sensitive membrane based on the colourimetric reagent Zincon," Talanta, vol. 47, no. 3, pp. 595-604, 1998.

[17] D. T. Newcombe, T. J. Cardwell, R. W. Cattrall, and S. D. Kolev, "An optical redox chemical sensor based on ferroin immobilised in a Nafion(B) membrane," Analytica Chimica Acta, vol. 401, no. 1-2, pp. 137-144, 1999.

[18] D. T. Newcombe, T. J. Cardwell, R. W. Cattrall, and S. D. Kolev, "Optical membrane redox chemical sensor for the determination of ascorbic acid," Laboratory Robotics and Automation, vol. 12, no. 4, pp. 200-204, 2000.

[19] O. S. Wolfbeis, N. V. Rodriguez, and T. Werner, "LEDcompatible fluorosensor for measurement of near-neutral $\mathrm{pH}$ values," Mikrochimica Acta, vol. 108, no. 3-6, pp. 133-141, 1992.

[20] G. E. Badini, K. T. V. Grattan, and A. C. C. Tseung, "Impregnation of a $\mathrm{pH}$-sensitive dye into sol-gels for fibre optic chemical sensors," The Analyst, vol. 120, no. 4, pp. 10251028, 1995.

[21] B. Kuswandi, A. A. Vaughan, and R. Narayanaswamy, "Simple regression model using an optode for the simultaneous determination of zinc and cadmium mixtures in aqueous samples," Analytical Sciences, vol. 17, no. 1, pp. 181-186, 2001.

[22] N. Mahendra, P. Gangaiya, S. Sotheeswaran, and R. Narayanswamy, "Investigation of a $\mathrm{Cu}(\mathrm{II})$ fibre optic chemical sensor using fast sulphon black F (FSBF) immobilised onto XAD-7," Sensors and Actuators B, vol. 81, no. 2-3, pp. 196-201, 2002.

[23] M. Lerchi, E. Bakker, B. Rusterholz, and W. Simon, "Leadselective bulk optodes based on neutral ionophores with subnanomolar detection limits," Analytical Chemistry, vol. 64, no. 14, pp. 1534-1537, 1992.

[24] K. Wang, K. Seiler, B. Rusterholz, and W. Simon, "Characterization of an optode membrane for zinc(II) incorporating a lipophilized analogue of the dye 4-(2-Pyridylazo)resorcinol," The Analyst, vol. 117, no. 1, pp. 57-60, 1992.

[25] G. R. Amiet, J. R. Farrell, P. J. Iles, and T. J. Sands, "An optode for the determination of copper, based on 4-decyloxy-2-(2pyridylazo)-1-naphthol immobilized in poly(vinyl chloride)," Australian Journal of Chemistry, vol. 54, no. 1, pp. 27-30, 2001.

[26] C. Sanchez-Pedreño, M. S. García, J. A. Ortuño, M. I. Albero, and E. Ballester, "Development of a new flow-through bulk optode for the determination of manganese(II)," Fresenius' Journal of Analytical Chemistry, vol. 369, no. 7-8, pp. 680-683, 2001.

[27] A. Safavi and M. Sadeghi, "Design and evaluation of a thorium (IV) selective optode," Analytica Chimica Acta, vol. 567, no. 2, pp. 184-188, 2006.

[28] M. Shamsipur, T. Poursaberi, A. Avanes, and H. Sharghi, "Copper(II)-selective fluorimetric bulk optode membrane based on a 1-hydroxy-9,10-anthraquinone derivative having two propenyl arms as a neutral fluorogenic ionophore," Spectrochimica Acta. Part A, vol. 63, no. 1, pp. 43-48, 2006.

[29] T. J. Sands, T. J. Cardwell, R. W. Cattrall, J. R. Farrell, P. J. Iles, and S. D. Kolev, "A highly versatile stable optical sensor based on 4-decyloxy-2-(2-pyridylazo)-1-naphthol in Nafion for the 
determination of copper," Sensors and Actuators B, vol. 85, no. 1-2, pp. 33-41, 2002.

[30] G. J. Moody and J. D. R. Thomas, Ion, Selective Electrodes in Analytical Chemistry, vol. 1, Plenum Press, New York, NY, USA, 1987.

[31] T. P. Byrne, Selective Electrode Reviews, vol. 10, p. 107, 1988.

[32] R. W. Cattrall and I. C. Hamilton, "Coated-wire ion-Selective electrodes," Ion-Selective Electrode Reviews, vol. 6, no. 2, pp. 125-172, 1984.

[33] G. J. Moody, R. K. Owusu, and J. D. R. Thomas, "Studies on crown ether based potentiometric sensors for 4,4"dipyridinium and related dications," Analyst, vol. 113, no. 1, pp. 65-69, 1988.

[34] A. Rouhollahi and M. Shamsipur, "Triiodide PVC membrane electrode based on a charge-transfer complex of iodine with 2,4,6,8-tetraphenyl-2,4,6,8-tetraazabicyclo[3.3.0]octane," Analytical Chemistry, vol. 71, no. 7, pp. 1350-1353, 1999.

[35] G. Mukherjee, S. N. Poddar, K. Choudhury, and K. Dey, "NS and NSO-Donor ligands and their metal complexes. Synthesis and characterisation of a new lowspin iron(III) complex with 1,2-di(o-aminophenylthio)ethane and iron(III), cobalt(III) and manganese(III) complexes of 1,2-di(o-salicylaldiminophenylthio)ethane," Transition Metal Chemistry, vol. 13, no. 1, pp. 58-63, 1988.

[36] W. E. Morf, K. Seiler, P. Sorenson, and W. Simon, Ion-Selective Electrodes, Akademia Kiado, Budapest, Hungary, 1989.

[37] E. Bakker, P. Bühlmann, and E. Pretsch, "Carrier-based ionselective electrodes and bulk optodes-1. General characteristics," Chemical Reviews, vol. 97, no. 8, pp. 3083-3132, 1997.

[38] T. Rosatzin, E. Bakker, K. Suzuki, and W. Simon, "Lipophilic and immobilized anionic additives in solvent polymeric membranes of cation-selective chemical sensors," Analytica Chimica Acta, vol. 280, no. 2, pp. 197-208, 1993.

[39] M. A. Simon and R. P. Kusy, "The molecular, physical and mechanical properties of highly plasticized poly(vinyl chloride) membranes," Polymer, vol. 34, no. 24, pp. 5106$5115,1993$.

[40] A. D. C. Chan and D. J. Harrison, "Carbon-13 spin-lattice relaxation studies of the effect of water on ion-selective electrode membranes," Talanta, vol. 41, no. 6, pp. 849-856, 1994.

[41] A. A. Ensafi and M. Bakhshi, "New stable optical film sensor based on immobilization of 2-amino-1-cyclopentene1-dithiocarboxylic acid on acetyl cellulose membrane for Ni(II) determination," Sensors and Actuators B, vol. 96, no. 12, pp. 435-440, 2003.

[42] M. K. Amini, T. Momeni-Isfahani, J. H. Khorasani, and M. Pourhossein, "Development of an optical chemical sensor based on 2-(5-bromo-2-pyridylazo) -5-(diethylamino)phenol in Nafion for determination of nickel ion," Talanta, vol. 63, no. 3, pp. 713-720, 2004. 


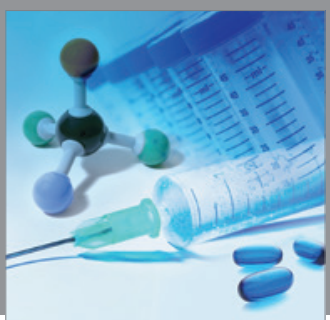

International Journal of

Medicinal Chemistry

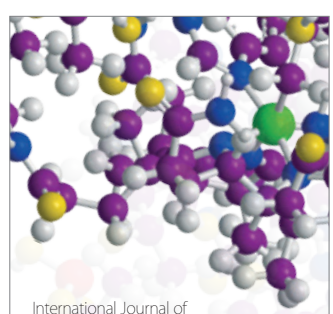

Carbohydrate Chemistry

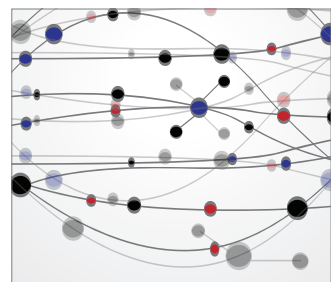

The Scientific World Journal
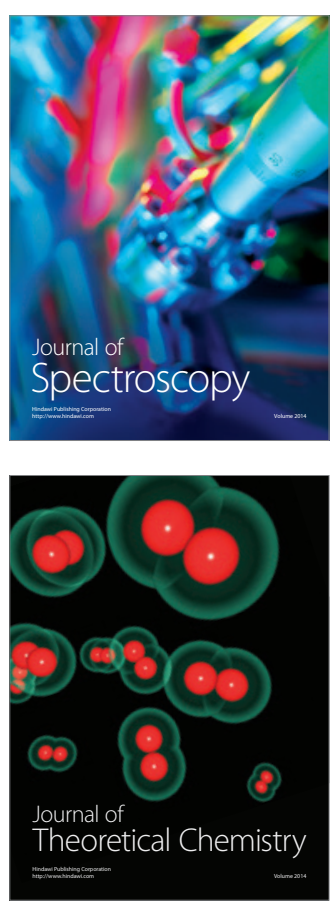
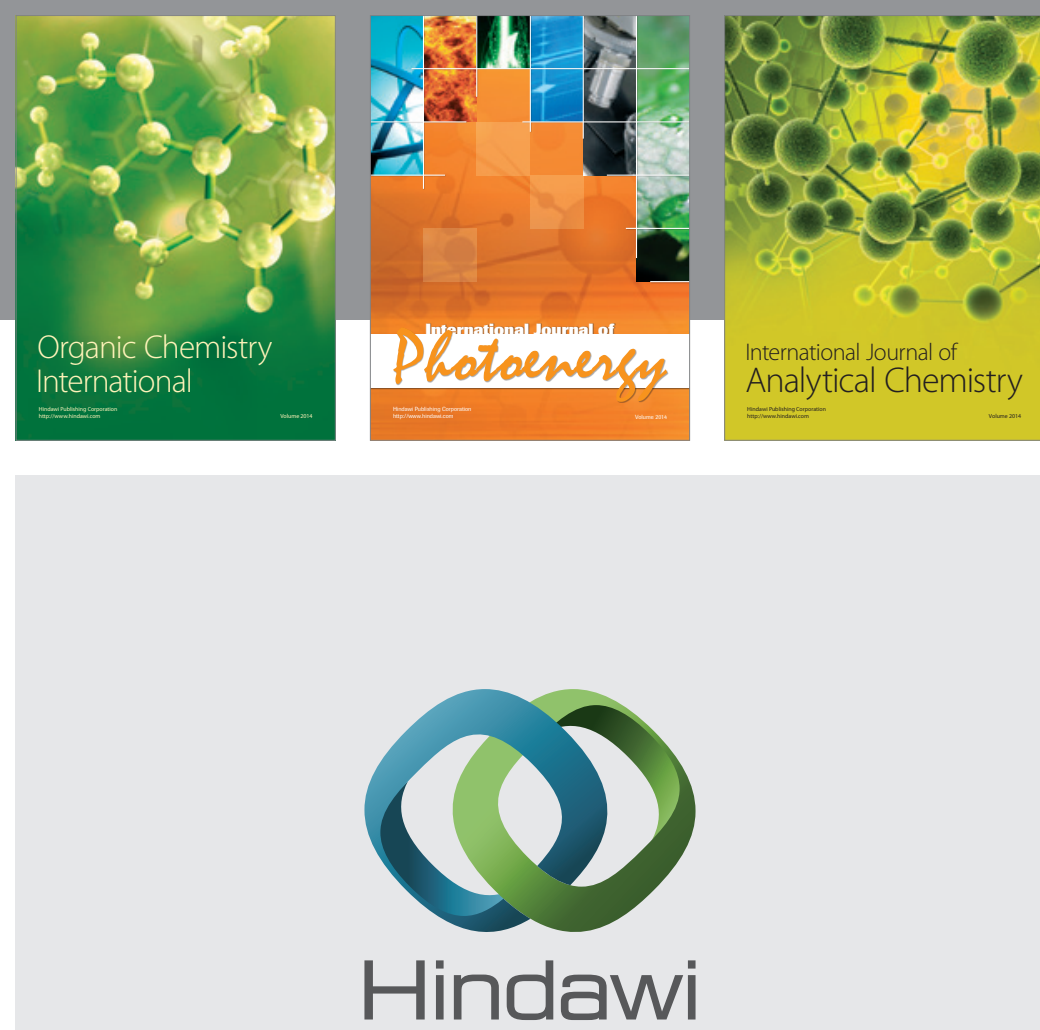

Submit your manuscripts at

http://www.hindawi.com
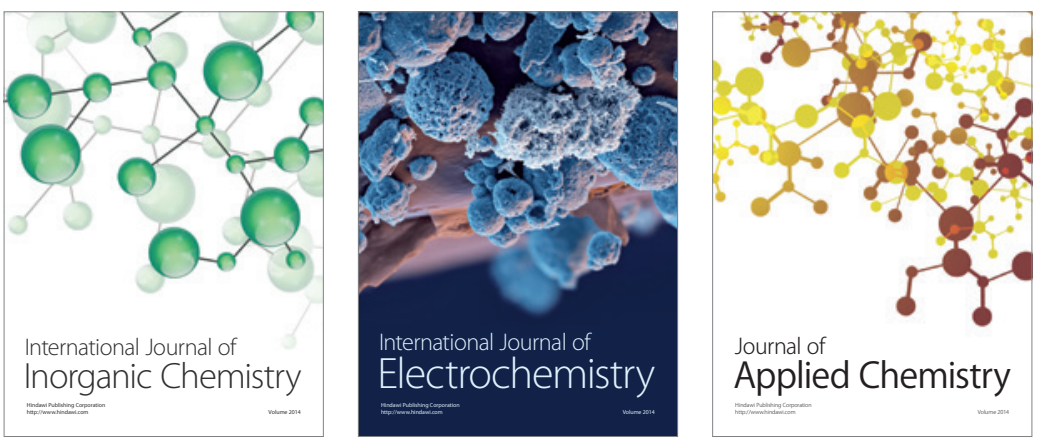

Journal of

Applied Chemistry
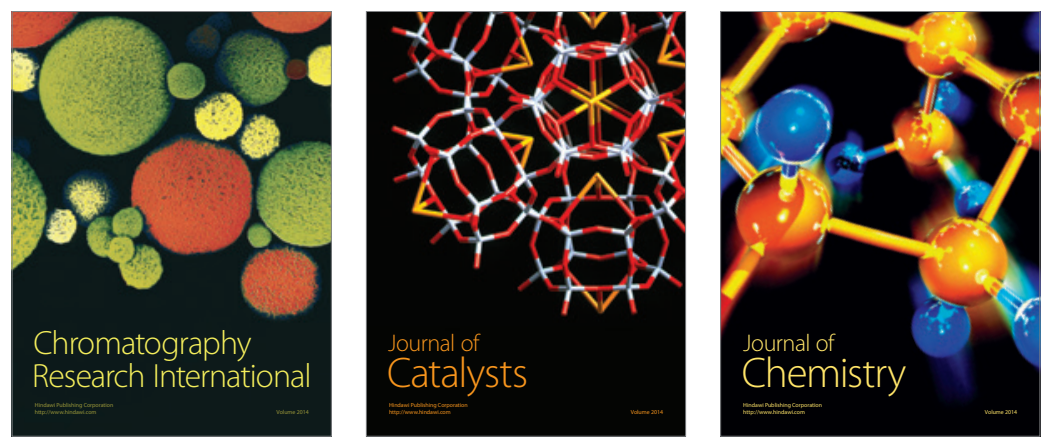
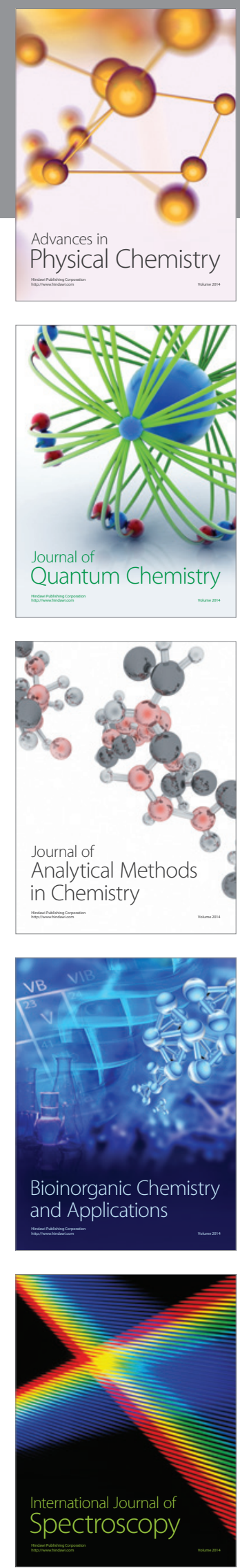